\author{
Ewa Młynarczyk \\ Uniwersytet Pedagogiczny w Krakowie
}

\title{
Terytorialna i kulturowa identyfikacja w krakowskich nazwach firmowych
}

\section{Wprowadzenie}

Wzrastające $\mathrm{w}$ ostatnich latach zainteresowanie nazewnictwem placówek handlowo-usługowych zaowocowało wieloma pracami z zakresu szeroko pojętej chrematonimii, w której omawia się ten stale rozrastający się zasób onimów, przyjmując różne perspektywy opisu: strukturalny, kulturowy, chronologiczny, terytorialny ${ }^{1}$. Wśród wielu zagadnień związanych z nazewnictwem miejskim szeroko omawiane jest także zagadnienie relacji między chrematonimią a toponimią, klasami onimicznymi, których wspólny zakres jest różnie postrzegany w zależności od przyjętych założeń: możliwe jest rozpatrywanie tej klasy onimów w ramach toponimii, czego zwolenniczką była m.in. E. Rzetelska-Feleszko, podkreślająca, że nazwy sklepów „mieszczą się w definicji toponimu jako »nieożywionego, naturalnego lub stworzonego przez człowieka obiektu na ziemi, wyróżniającego się spośród innych «" [Rzetelska-Feleszko 1996: 283]. Podobne stanowisko zajął Cz. Kosyl [Kosyl 2003: 370]. W ostatnich latach zazwyczaj nazwy obiektów handlowo-usługowych omawia się w ramach chrematonimii, wręcz nawet, na co zwrócił uwagę A. Gałkowski, zawęża się niejako postrzeganie chrematonimów, wyłącznie lub głównie, do nazw firmowych, posługując się w ich opisie wyrażeniami typu »kielecka chrematonimia«, »olsztyńskie chrematonimy«, »chrematonimy udomowione« [Gałkowski 2008: 37]. Te dwa ujęcia, jak podkreśla A. Gałkowski, nie muszą być sprzeczne, w jego opinii „tworzą one ambiwalentny dyskurs nazewniczy, w którym da się zastosować tradycyjne metody badawcze, wypracowane przez toponomastykę, a jednocześnie podpinają się one pod złożone nazewnictwo chrematonimiczne nowej ery, które odkrywa różnorodne walencje identyfikacyjne" [Gałkowski 2008: 39].

${ }^{1}$ Syntetyczny opis problematyki i obszerną literaturę z zakresu tych badań przynoszą m.in. prace o charakterze monograficznym A. Gałkowskiego [2008] i A. Siwca [2012]. 
Bez względu na przyjętą koncepcję obie klasy onimów (toponimy i firmonimy) traktuje się jako odrębne i swoiste przy rozpatrywaniu struktury nazw, bowiem jedną $\mathrm{z}$ wyrazistych tendencji nazwotwórczych w ramach chrematonimii jest kreacja nazw na podstawie jednostek $\mathrm{z}$ innych kategorii onomastycznych, w tym toponimów [Rzetelska-Feleszko 1994: 134; Cieślikowa 1996: 11; Gałkowski 2008: 231].

\section{Firmonimy detoponimczne}

W niniejszym artykule pragnę przedstawić, na przykładzie konkretnego materiału egzemplifikacyjnego ograniczonego terytorialnie, sposoby wykorzystania różnego typu nazw geograficznych w nazewnictwie firmowym. Przedmiotem mojego zainteresowania stały się krakowskie firmonimy, które w zamierzeniu ich twórców mają podkreślać związek firmy bądź instytucji z miejscem jej funkcjonowania, przyczyniać się do jej geograficznej i kulturowej identyfikacji, stanowiąc tym samym przejaw tendencji do podkreślania lokalnej tożsamości, w przeciwieństwie do silnych procesów globalizacyjnych przejawiających się w ostatnich latach w języku i w kultu$\mathrm{rze}^{2}$. Wzięłam pod uwagę nazwy obiektów handlowo-usługowych (firmonimy ${ }^{3}$ ) oraz nazwy instytucji użyteczności publicznej (domów kultury, przychodni, kin, klubów sportowych), w ujęciu Gałkowskiego tworzące strefę przejściową między chrematonimią marketingową a społecznościową, w której ramach mieszczą się nazwy grup społecznych, np. stowarzyszeń, partii, organizacji [Gałkowski 2008: 119]. Przedmiot opisu będą stanowić zatem nazwy zawierające w swej strukturze jakiekolwiek odniesienie do miejsca, w którym usytuowana jest siedziba firmy bądź instytucji. Interesował mnie sposób wykorzystania różnych klas toponimów stanowiących podstawę nazwotwórczą, ich udział w strukturze chrematonimów, a także różne płaszczyzny przejawiania się funkcji lokalizującej w powstałych w ten sposób firmonimach.

Przy rozpatrywaniu podstaw nazwotwórczych biorę pod uwagę wyłącznie urbanonimy należące do miejskiego nazewnictwa w Krakowie. Wśród nazw stanowiących podstawę tworzenia firmonimów znalazły się nazwy wszystkich typów obiektów miejskich wyróżnionych przez K. Handke: obszarów (dzielnic, osiedli), traktów (ulic, alej, rzek) i punktów, czyli obiektów stale umiejscowionych przestrzennie, m.in. placów, budowli użyteczności publicznej i innych, jak bramy, baszty, rogatki, forty, kościoły [Handke 1992: 66].

${ }^{2}$ Procesy globalizacyjne przejawiają się współcześnie najsilniej w nazwach handlowych [Rzetelska-Feleszko 2006b: 32].

${ }^{3} \mathrm{~W}$ pracach z zakresu chrematonimii istnieje duże zróżnicowanie terminologiczne [Gałkowski 2008: 37-38]. W niniejszym artykule w odniesieniu do nazw firm będę się posługiwać terminem firmonim, który w ocenie A. Gałkowskiego jest ,z chronomastycznego punktu widzenia, najbardziej uniwersalnym pojęciem dla rozpatrywanych w CHM (chrematonimii marketingowej) nazw obiektów” [tamże: 64]. Stosuję również za A. Siwcem termin o charakterze deskryptywnym „,nazwy obiektów handlowo-usługowych" [Siwiec 2006]. 


\section{Firmonimy derywowane od nazwy miasta}

Ze względu na specyfikę Krakowa i rolę tego miasta w historii Polski oraz znaczenie w światowym dziedzictwie kulturowym część nazw, zachowując indywidualną identyfikację, ma o wiele szerszy zasięg - narodowy, a nawet uniwersalny ${ }^{4}$. Najbardziej wyrazistym przykładem tego zjawiska jest urbonim Kraków, z którym związane są konotacje architektonicznego piękna, swoistej „,nobliwości” wynikającej z zabytkowego charakteru miasta, „kulturowości’ i szczególnej atmosfery wynikającej m.in. z faktu, że Kraków to duże centrum akademickie i naukowe. Eksplikacją tychże konotacji, utrwalanych w rozmaitych przekazach literackich i medialnych, jest nazwa oficjalnej strony internetowej krakowskiego urzędu miasta zawierająca przymiotnik często pojawiający się w języku mediów: Magiczny Kraków ${ }^{5}$.

Nazwa miasta występuje w wielu krakowskich firmonimach, w postaci polskiej Kraków, łacińskiej Cracovia albo angielskiej Cracow i jest używana w różnych miejscach struktury nazewniczej, np. Kraków Travel, Cracovia Investment, Sita Kraków, Iglotech-Kraków, Computer Plus Kraków, Cracow Medical Center, Cracow On Tour; City Tour Kraków. Sporo firm zawiera przymiotnik odmiejscowy, np. Galeria Krakowska, Klinika Krakowska, Gospoda Krakowska. Zdarzają się też firmonimy z niemianownikową postacią toponimu, np. Ciasteczka z Krakowa - nazwa firmy cukierniczej.

Zaskakujący jest fakt, że do wspomnianych konotacji wprost nawiązuje jedynie firmonim Czar Krakowa nazywający firmę zajmującą się hodowlą psów, znajdującą się na os. Centrum A w Nowej Hucie, dzielnicy znacznie oddalonej od Starego Miasta, z którym związane są asocjacje „magiczności”.

Do urbonimu Kraków odwołują się także firmonimy z charakterystyczną, łatwo rozpoznawalną cząstką, -krak- lub -crak- w rozmaity sposób połączoną z innymi elementami językowymi tworzącymi firmonim, np. Krakszkło, Stal-Krak, Krak Granit, Krak-Mafish, Auto-Krak, El-Krak, Krak Dach, Pol-Krak-Nomad, Crak-Cold-Servis, Tech-Krak, Krak Center, Krakszkło, Krak-Net-Telekom, Krak Time, Crak Cold Serwis, Crack-on Transport, Krakor, Mixkrak, Krakinform. Nazwy tego typu, ze względu na różnorodność cząstek i możliwości ich łączenia nazwane przez E. Rzetelską-Feleszko »zlepkowcami« [Rzetelska-Feleszko 2006: 160], są tworzone niemal seryjnie, czemu sprzyja łatwość wydzielenia cząstki -krak- i łączenia jej z innymi ${ }^{6}$.

${ }^{4}$ Funkcjonowanie nazw własnych w zasięgu indywidualnym, narodowym bądź uniwersalnym omawia A. Cieślikowa, posługując się m.in. przykładem urbonimu Kraków jako nazwy o zasięgu uniwersalnym [Cieślikowa 1992].

${ }^{5}$ Strona int.: http://www.krakow.pl/ (dostęp: 21.12.2012.).

${ }^{6}$ Przykłady podobnych struktur nazewniczych z innych miast, m.in.. z Lublina i i Warszawy podaje A. Siwiec [Siwiec 2012:143], jednak są one rzadziej reprezentowane niż w firmonimach krakowskich. 
Nazwę Krak, którą przyjmuje również wiele firm, można interpretować dwojako: jako czastkę derywowaną od urbonimu Kraków lub jako nazwę tożsamą $\mathrm{z}$ antroponimem nazywającym legendarnego założyciela miasta.

Do urbonimu Kraków nawiązują również firmonimy, w których użyty został skrót $K R K$, rozpowszechniony przez ludzi młodych preferujących krótkie formy w komunikacji telefonicznej czy elektronicznej, używany na podkrakowskim lotnisku Balice, a ostatnio promowany przez władze Krakowa. Skrót ten ma być nowoczesnym symbolem identyfikacji wizualnej miasta w materiałach promocyjnych. My KRK to nazwa pierwszej oficjalnej krakowskiej aplikacji dla telefonów z systemem Android, czyli z oprogramowaniem offline, które po zainstalowaniu przekazuje różne praktyczne informacje, np. adresy punktów informacji turystycznej, opisy wybranych tras turystycznych, informacje o atrakcjach Krakowa, mapę miasta. Przygotowywane są także broszury, koszulki z kolorowym napisem KRK czy różne gadżety reklamujące charakterystyczne krakowskie miejsca, np. $\mathrm{ZOo}^{7}$. Zanim skrótowiec KRK stał się nowoczesnym symbolem Krakowa, był używany jako składnik kilku krakowskich firmonimów, m.in. Budosquad KRK (firma glazurnicza), Micro-Krk (firma handlowa z branży samochodowej), Krk Techno$\operatorname{logy}$ (telefony komórkowe), Krk Bud (firma budowlana).

\section{Firmonimy derywowane od nazw dzielnic i osiedli}

W nazewnictwie firmowym wykorzystuje się również inne toponimy, m.in. nazwy krakowskich dzielnic i osiedli. Znakomita większość z nich to pierwotnie, jak w większości miast polskich, nazwy odrębnych wsi, stopniowo włączanych w granice administracyjne Krakowa. W firmonimach nazwy te są używane zazwyczaj transonimizacyjnie, np. Hotel Podgórze, Pizzeria Bronowice, Agencja Ubezpieczeniowa Prqdnik, Apartament Salwator, Apartamenty Ludwinów, lub $z$ przyimkiem - Gospoda Na Woli (usytuowana na Woli Justowskiej). Odrębnym członem wskazującym na bardzo dobrą ze względów marketingowych lokalizację jest Stare Miasto, ang. Old Town, Old City, Aparthotel Stare Miasto - Hotel Old Town, Old City Apartaments. Funkcję lokalizującą w chrematonimach użytkowych pełnią także człony w postaci przymiotnika utworzonego od nazwy dzielnicy: Śródmiejskie Centrum Kultury, Zwierzyniecka Firma Handlowo-Ustugowa, Centrum Biznesu Brama Bronowicka. Nazwa jednej z najbardziej rozpoznawalnych w kraju i na świecie starej dzielnicy Krakowa, Kazimierz, niegdyś miasta nazwanego tak na cześć założyciela, króla Kazimierza Wielkiego, jest ze względów

${ }^{7} \mathrm{O}$ rozporządzeniu w sprawie skrótu KRK jako symbolu miasta oraz kontrowersjach z tym związanych można przeczytać w artykule zamieszczonym na stronie internetowej „Gazety Wyborczej”: http://krakow.gazeta.pl/krakow/1,44425,11499444,Byl_Krakow_bedzie_KRK_Nowy_znak_miasta.html\#ixzz29T6V178a (dostęp: 13.10.2012). 
marketingowych chętnie wykorzystywana przez właścicieli hoteli i pensjonatów goszczących wielu zagranicznych turystów, np. Hotel Kazimierz, Kazimierz's Secret Apartaments, Kazimierz Apartaments, Na Kazimierzu. Sekret Kazimierza, Atrakcyjny Kazimierz.

Od nazw dzielnic, historycznie stanowiących odrębne miejscowości, zostały nazwane przez transonimizację również centra handlowe, zwane galeriami ${ }^{8}$, które stały się nowymi wyrazistymi punktami miejskiej geografii: Bonarka City Center, Centrum Handlowe Czyżyny. Ostatni z przytoczonych przykładów dotyczy jednej z wielu wsi włączonych do najmłodszej dzielnicy Krakowa - Nowej Huty, gdzie obok dawnego nazewnictwa, m.in. Bieńczyce, Mistrzejowice, Pleszów, Mogiła, istnieją nazwy dzielnic narzucone administracyjnie, m.in. osiedla Teatralne, Urocze, Kolorowe, Piastów, Zgody, Tysiaclecia, Krakowiaków, Wandy, Centrum, z podziałem na Centrum $A, B, C, D, E$. Niektóre z nich stały się inspiracją do powstania firmonimów, np. na Osiedlu Piastów funkcjonują: Centrum Medyczne Piast, Plac Targowy Piast, Apteka Piastów, na osiedlu Centrum E - Hotel Centrum.

Nazwy osiedli mogą być podstawą gier językowych ${ }^{9} \mathrm{w}$ firmonimach, np. nazwa delikatesów Żabcia, to firmonim tożsamy ze zdrobnieniem apelatywu żaba, ale zarazem nawiązujący do toponimu Żabiniec, nazwy osiedla powstałego w 1995 r., gdzie ten sklep się znajduje.

Inne nowe osiedle krakowskie oraz główna ulica tam przebiegająca noszą nazwę Kuźnicy Koltatajowskiej. W nazewnictwie firmowym przejęto pierwszy człon onimu: Kuźnica Market, Kuźnica Nieruchomości, który w firmach z siedzibą na tym osiedlu ma wyrazistą dla mieszkańców funkcję lokalizującą. W oddziałach firmy usytuowanych w różnych punktach miasta motywacja firmonimów staje się nieczytelna ${ }^{10}$.

\section{Firmonimy derywowane od nazw ulic}

Kolejnym typem toponimów wykorzystywanych w nazewnictwie firmowym są nazwy ulic, często bez jakichkolwiek zmian (w procesie transonimizacji) przenoszone na nazwę firmową: Hotel Kolna, Schronisko Młodzieżowe Oleandry, Studio Wolnica, Apteka Czarnowiejska. W większości przypadków, zwłaszcza gdy nazwa dostosowana jest składniowo do członu nazywającego typ firmy,

${ }^{8}$ Nazywanie galerii handlowych od nazw dzielnic jest tendencją widoczną również $\mathrm{w}$ innych miastach [Siwiec 2012: 125].

${ }^{9} \mathrm{~W}$ nazewnictwie uzualnym często stosowane są różnego typu gry językowe [Rutkiewicz-Hanczewska 2007].

${ }^{10}$ Być może wtedy aktualizowane jest znaczenie przenośne apelatywu kuźnica 'miejsca kształtowania, formowania czegoś, np. idei, myśli lub ludzkich postaw’ [SJPD]. Konotacje związane z tym leksemem wykorzystali m.in. twórcy stowarzyszenia Kuźnica skupiającego aktywnych intelektualnie przedstawicieli różnych środowisk i zawodów, działających społecznie. 
wykorzystuje się nie tylko jej funkcję lokalizacyjną, ale także konotacje związane z wyrazem, od którego powstał toponim, np. 'prestiż', 'tradycja', 'historyczność' w firmonimach Cukiernia Jagiellońska, Cukiernia Królewska, Bar Królewski, Galeria Grodzka.

Nazwy ulic stanowią także podstawę wielu firmonimów aluzyjnych, wykorzystujących zjawisko polisemii i homonimii leksykalnej, np. nazwa restauracji Karmela - ze względu na lokalizację jest motywowana nazwą ulicy Karmelickiej, a ze względu na typ działalności - apelatywem karmel 'cukier w temperaturze topliwości przekształcający się w ciagła, niekrystaliczną masę barwy brązowej' [SJPD]. Dwuznaczność tę wykorzystano również w nazwie zlokalizowanej przy tej samej ulicy cukierni Karmelek, firmonimu tożsamego z apelatywem karmelek 'cukierek z karmelu twardy lub nadziewany' [SJPD]. Podobną grę językową zastosowano w innych przypadkach: Bar Raj przy ul. Rajskiej, Hotel Gródek przy ul. Na Gródku, Pracownia Twórcza Aleja (przy alei Krasińskiego). Angielską składnię zachowuje nazwa Młyn Fitness nawiązująca w pierwszym członie do siedziby przy ul. Dolnych Młynów.

Często w wyniku kreacji onomastycznej powstaje nazwa tożsama z antroponimem: Hotel Floryan przy ul. Floriańskiej, Hotel Mikołaj przy ul. Mikołajskiej, Hotel Matejko przy pl. Matejki, Hotel Piast przy ul. Piastowskiej, Studio Felicjanki przy ul. Felicjanek. Aluzyjność innego typu zawiera nazwa hotelu Fryde$r y k$, tożsama z imieniem patrona ulicy, Fryderyka Szopena.

Inspiracją do gier językowych stała się nazwa jednej z krakowskich ulic Miodowa - w dwóch nazwach firm tam ulokowanych wykorzystano konotacje związane z apelatywem miód: restauracja Miodowe Smaki i hostel - Honey, reklamowany również pod polskojęzyczną nazwą Miodowy. Do nazwy dostosowano elementy plastyczne wykorzystywane w celach reklamowych - strona internetowa w żółtym kolorze, napisy w ramkach mających kształt plastra miodu, takiego samego kształtu litery $o$ w logo firmy, zdjęcie słoika z miodem na tle Wawelu.

Innym sposobem powiązania nazwy firmy z jej lokalizacją jest umieszczenie w strukturze firmonimu elementów składowych adresu. Może to być nazwa ulicy i numer lokalu, np. Hotel Rynek 7, Cafe Gotębia 3, Hostel Aleje 28, skrót nazwy ulicy Fl-51 (Floriańska 51), B-32 (Brogi 32), B4 (Bracka 4) lub sam numer łączony z członami oznaczającymi najczęściej typ lokalu ${ }^{11}$ : No 7 Lounge Bar (Rynek 7), Cafe 7 (pl. Nowy 7), Sklep 10 (ul. Basztowa 10), Bar 13 (Rynek 13), żartobliwie Stodoła 47 (ul. Floriańska 47). W niektórych nazwach widoczna jest stylizacja na potoczną odmianę polszczyzny: w użyciu derywatów rzeczownikowych od liczebników nazywających numer lokalu: Jedynka (ul. Teligi 1), Dwójka (ul. Słoneckiego 2), Piqtka. Pasmanteria, rajstopy, bielizna (ul. Konarskiego 5), nazwy z przyimkiem pod i rzeczownikiem odliczebnikowym, zapisywanym zazwyczaj częściowo

${ }^{11} \mathrm{~W}$ strukturze takich nazw toponim nie jest wyrażony wprost, ale jest elementem domyślnym, jest to tzw. toponim in absentio [Siwiec 2012]. 
za pomocą cyfr: Ogród pod 16, Kwiaciarnia pod 12-kq, Bistro pod Trzynastka, Pub pod 3, Pod 13-ka (bar).

W niektórych firmonimach wykorzystano potoczne, żartobliwe określanie ulic według modelu amerykańskiego, np. 8 Aleja - restauracja przy al. Krasińskiego 8 czy Art Club przy 29-tej (przy alei 29 Listopada, nazywanej potocznie 29. Aleja).

Adres lokalu stwarza też okazję do innych gier językowych, jak np. dostosowanie składniowe członów, powodujące powstanie połączenia o nowych konotacjach - Bajeczna Piatka, nazwa firmy mieszczącej się przy ul. Bajecznej 5, lub utworzenie rymowanki MDK na 102 (Młodzieżowy Dom Kultury przy al. 29. Listopada 102). Oryginalność i pomysłowość wyróżnia nazwę jednego z pubów, ponieważ ma ona formę opisowej wskazówki dojścia do lokalu Pierwszy lokal na Stolarskiej po lewej stronie idac od Matego Rynku. Nazwę tę przytacza A. Siwiec, podając ją jako przykład wyjątkowej kreacji onimicznej, w której „mapa, jej fragment, wchodzi do nazwy, a obiekt, do którego ta nazwa się odnosi, stanowi jakby punkt docelowy w wędrówce po mieście" [Siwiec 2012: 120].

W jednym przypadku podstawowym zamysłem twórczym stało się mylne (wprowadzające w błąd) oznaczenie miejsca w nazwie pubu Róg Brackiej i Reformackiej, usytuowanego przy ul. Reformackiej, która nigdzie nie krzyżuje się z ul. Bracką, ponieważ są to ulice po dwóch stronach krakowskiego Rynku Głównego. Ten pozorny adres służył podobno jako powiedzenie stosowane w sytuacji, gdy ktoś dawał do zrozumienia interlokutorowi, że nie zamierza się z nim spotkać lub gdy chciał celowo wprowadzić w błąd osobę spoza Krakowa ${ }^{12}$.

\section{Firmonimy derywowane od nazw rzek}

Odrębną kategorią nazw, najrzadziej wykorzystywaną w firmonimii, są nazwy rzek: najbardziej znanej i najdłuższej rzeki w Polsce - Wisty: Apartament Wisła i Agencja Nieruchomości Wista Kraków, tożsama z nazwą najstarszego krakowskiego klubu sportowego, i znanych raczej tylko lokalnie - Wilgi i Rudawy: Hotel Wilga, Pensjonat B\&B nad Rudawq, Agencja Nieruchomości Nad Rudawa.

\section{Firmonimy derywowane od nazw znanych obiektów}

Mówiąc o toponimicznym charakterze krakowskich firmonimów, nie można pominąc takich, których struktura nawiązuje do ważnych kulturowo obiektów nazewniczych. Czesść z nich to miejsca i budowle o bardzo wysokiej randze, reprezentacyjne w skali nie tylko krajowej, ale nawet światowej, jak Wawel i Sukiennice. Inne są

${ }^{12}$ Strona int. http://www.gastronauci.pl/pl/4017-rog-brackiej-i-reformackiej-krakow (dostęp: 17.10.2013). 
również szeroko znanymi obiektami zabytkowymi: Brama Floriańska, Barbakan, krakowskie kopce, zwłaszcza Kopiec Kościuszki i Kopiec Piłsudskiego. Znanym traktem w zabytkowej części Krakowa są Planty, ciagg zieleni okalający Stare Miasto.

Twórcy firmonimów sięgnęli również do tej warstwy nazewniczej. Przez wiele lat nazwę Wawel nosiły dwie duże instytucje: jedna z najstarszych firm cukierniczych w Polsce ${ }^{13}$ oraz klub sportowy założony w 1919 r. [EK: 1033]. W ciągu ostatnich dwudziestu lat Wawel stał się nazwą lub członem nazwy (także w postaci przymiotnikowej) różnych firm np. Hotel Wawel, Wawel Radio Taxi, Automobilklub Wawelski, Wawel Service, Wawel-Dom, Angel Wawel. W większości przytoczonych przykładów nazwa Wawel nie jest związana z lokalizacją firmy, ma raczej wywoływać skojarzenia z Krakowem, dla którego Wzgórze Wawelskie wraz z Zamkiem Królewskim stanowią wyrazisty symbol. Podobną funkcję mają pełnić firmonimy z nazwami Smocza Jama (nazwa hotelu i restauracji) i Barbakan: Radio Taxi Barbakan ${ }^{14}$, Kompania Regionalna Barbakan (firma zajmująca się skupem metali żelaznych, z siedzibą znacznie oddaloną od Śródmieścia).

Funkcję lokalizującą polegającą na dokładnym wskazywaniu miejsca siedziby firmy pełnią nazwy z przyimkiem lokatywnym: Hotel Pod Wawelem czy Restauracja Pod Smoczq Jamq.

Ścisłe powiązanie firmonimów z lokalizacją występuje w nazwach nawiązujących do kilku innych znanych krakowskich zabytków i miejsc. Są to: Café Sukiennice i Galeria Sukiennice (miejsce wystaw i sprzedaży sztuki współczesnej) umiejscowione w budynku tego najstarszego domu towarowego, Brama Hostel obok Bramy Floriańskiej, Hotel Pod Kopcem i Apteka Pod Kopcem, firmy usytuowane w pobliżu Kopca Kościuszki, Kebabownia Na Plantach i Hostel Na Plantach, firmy położone tuż przy parku okalającym Stare Miasto.

Niektóre nazwy pełnią funkcję pamiątkową, np. nazwa hotelu Pod Sikornikiem przypomina o dawnej nazwie Wzgórza św. Bronisławy, na której został usypany Kopiec Kościuszki. Podobną funkcję pełni nazwa osiedla deweloperskiego Willa Sowiniec, tożsama z nazwą wzgórza, na szczycie którego znajduje się inny znany krakowski kopiec, poświęcony Józefowi Piłsudskiemu.

Dokładną lokalizację wskazują także chrematonimy użytkowe powstałe od nazw słynnych krakowskich pałaców, kamienic i willi: Klub Piwnica pod Baranami i Kino pod Baranami znajdujące się w Pałacu Pod Baranami, Klub Pod Jaszczurami w kamienicy Pod Jaszczurką (pot. Pod Jaszczurami) [EK: 371], Kawiarnia Krzysztofory - umiejscowiona obok pałacu o nazwie Krzysztofory, siedziby Muzeum Historycznego Miasta Krakowa, Centrum Konferencyjne i Restauracja Willa Decjusza, mające siedzibę w renesansowym pałacyku o tej samej nazwie,

${ }^{13}$ Zakłady Cukiernicze Wawel powstały w $1951 \mathrm{r}$. z połączenia 3 przedwojennych fabryk cukierniczych, jej najbardziej rozpoznawalne produkty noszą nazwy wskazujące na lokalizację: bombonierka Wawel, czekolada Krakowska Gorzka, Mieszanka Krakowska.

${ }^{14}$ Firmonimy z członem Barbakan występują również w innych miastach, w których istnieją nazywane tak budowle, m.in. w Warszawie [Siwiec 2012: 119]. 
oraz znajdująca się tuż obok stadnina koni Decjusz, Księgarnia Hetmańska umiejscowiona na parterze Kamienicy Hetmańskiej, jednej z najważniejszych budowli średniowiecznego Krakowa, Restauracja i Bar Szara w Szarej Kamienicy, Restauracja Cechowa działająca w kamienicy będącej siedzibą Małopolskiej Izby Rzemiosła i Przedsiębiorczości.

Lokalizację firmy wskazują także firmonimy, których struktura została powiązana z nazwami budynków znanymi raczej lokalnie: Bunkier Sztuki Cafe, Hotel Korona i Apteka Pod Korona, znajdujące się obok Klubu Sportowego Korona, czy Restauracja Pod Strzelnica wykorzystująca bliskość charakterystycznej budowli - zabytkowej XIX-wiecznej strzelnicy garnizonowej.

Kilka nazw firm i instytucji wskazuje na lokalizację w jednym z fortów (lub w jego pobliżu) - budowli obronnych zbudowanych w XIX i XX w. wokół Krakowa ${ }^{15}$, z których część (nadająca się do użytku) jest obecnie wykorzystywana na różnego typu działalność. W nazwie zaznacza się położenie w pobliżu tego typu obiektu, np. Firma Deweloperska Pod Fortem, lub jego dokładną lokalizację, wskazywaną ogólnie - Hurtownia Win VinFort lub szczegółowo - poprzez numer (według oficjalnej numeracji) i/lub nazwę dzielnicy Fort 39 Ośrodek Szkolno-Wypoczynkowy, Fort 49 Krzesławice Młodzieżowy Dom Kultury, Klub Muzyczny Forty Kleparz. Nazwy tego typu pełnią potrójną funkcję: charakteryzują typ budowli, w którym ma siedzibę dana instytucja lub firma, wskazują jej lokalizację oraz upamiętniają historyczne budowle i ich oznaczenia.

O pamiątkowej funkcji firmonimów można mówić także w przypadku nazw firm umiejscowionych w pobliżu dawnych punktów poboru ceł. Nazwę Rogatka noszą firmy przy Królowej Jadwigi i przy ul. Rakowickiej, tam też znajduje się Restauracja Przy Rogatce.

Pamiątkowy charakter noszą również nazwy firm wskazujące na inną firmę czy instytucję działającą dawniej w tym samym miejscu, np. Klub Muzyczny Stara Kotłownia, Klub Fabryka.

\section{Podsumowanie}

Ukazane w referacie nazwy krakowskich firm i instytucji poprzez detoponimiczną podstawę pełnią funkcję lokalizujacą, realizowaną na różnym stopniu konkretyzacji. Mogą one wskazywać usytuowanie siedziby firmy: 1) ogólnie w Krakowie (firmonimy z członem Kraków, Cracovia, Cracow, -krak- i -crak, KRK, Wawel, Smocza Jama, Barbakan); 2) w jednej z krakowskich dzielnic (nazwy transonimizacyjne, np. Hotel Ludwinów, z członem przymiotnikowym, np. Brama Bronowicka, aluzyjne, np. Plac Targowy Piast na os. Piastów, Delikatesy Żabcia na os. Żabiniec); 3) przy konkretnej ulicy (nazwy transonimizacyjne,

${ }^{15}$ Całość obwarowań nazywana jest Twierdzq Kraków [EK: 1012]. 
np. Hotel Kolna i aluzyjne, np. Bar Raj przy Rajskiej, Hotel Mikołaj przy Mikołajskiej); 4) pod konkretnym adresem (nazwa tożsama z nazwą ulicy bądź jej skrótem lub/i z numerem lokalu, np. Cafe Gołębia 3, Fl-51, Cafe 7, Jedynka, Bistro pod Trzynastka); 5) obok znanego obiektu, w nazwach z przyimkiem pod, np. Pod Wawelem, i w nazwach aluzyjnych, np. Brama Hostel, Stadnina Koni Decjusz; 6) wewnątrz znanego obiektu, transonimizacyjnie, np. Café Sukiennice, łącznie z pełnym oznaczeniem, np. Fort 49 Krzestawice ${ }^{16}$.

Omówione typy nazewnictwa firmowego, występujące również w innych polskich miastach, stanowią przejaw swoistego terytorializmu. Jak pisze A. Siwiec, ,nazwy motywowane lokalizacją obiektu pełnią generalnie wobec odbiorcy przekazu językowego funkcję percepcyjno-orientacyjną, ich szczególna rola polega na tym, że dają wyobrażenie o miejscu obiektu w systemie miejskich koordynat. Jeśli są to nazwy związane z lokalną tożsamością mieszkańców miasta, to możemy im też przypisać funkcję zakorzeniającą" [Siwiec 2012: 124]. W przypadku firmonimów odwołujących się do nazwy dawnej stolicy Polski oraz do nazw kojarzonych z tym miastem obiektów zabytkowych, możemy dostrzec również chęć wpisania firmy w nazewnictwo związane z kulturowym dziedzictwem o zasięgu narodowym, a nawet uniwersalnym.

Odwołania do toponimów są w firmonimach także elementami funkcji perswazyjnej, polegającej na wzbudzaniu u odbiorcy pozytywnych emocji [Rutkowski 2001: 24], w przypadku nazw obiektów znanych lokalnie - poczucia swojskości i bliskości, w przypadku nazw o szerszym zasięgu - dumy wynikającej z przynależności do miejsca znanego i podziwianego w świecie.

Krakowskie chrematonimy detoponimiczne pełnią często także funkcję pamiątkową [Rutkowski 2001: 18]: utrwalają dawne, dziś nieużywane nazewnictwo dzielnic (np. Bonarka), przypominają miejsca historycznie ważne dla miasta (np. Sowiniec), stanowią nieraz jedyną pamiątkę po danym obiekcie (Klub Muzyczny Fabryka).

\section{Wykaz skrótów}

EK - Stachowski Antoni Henryk (red.), 2000, Encyklopedia Krakowa, Warszawa-Kraków

SJPD - Doroszewski Witold (red.), 1961, Stownik języka polskiego, t. III, Warszawa

${ }^{16} \mathrm{Na}$ osobną uwagę zasługuje fakt, że między lokalizacją wskazywaną w niektórych firmonimach a faktyczną siedzibą firmy występuje rozbieżność wynikająca m.in. z tworzenia oddziałów w innych miejscowościach, a nawet krajach, np. Krakszkło w Niepołomicach, Stal-Krak $-w$ kilku państwach europejskich. Rozbieżność taka może być jednak świadomym zabiegiem marketingowym polegającym na skorzystaniu z renomy dużego miasta, jak w przypadku firmy Krak-Stone, z siedzibą w Górze Libertowskiej - podkrakowskiej wsi. W przypadku nazwy centrum handlowego Kazimierz nazwa wprowadza w błąd, ponieważ jest ono usytuowane poza granicami dawnego królewskiego miasta. 


\section{Bibliografia}

Cieślikowa Aleksandra, 1996, Metody w onomastycznych badaniach różnych kategorii nazw własnych, „Onomastica” XLI, 5-19.

Encyklopedia Krakowa, 2000, red. Antoni Henryk Stachowski, Warszawa-Kraków.

Gałkowski Artur, 2008, Chrematonimy w funkcji kulturowo-użytkowej. Onomastyczne studium porównawcze na materiale polskim, włoskim, francuskim, Łódź.

Handke Kwiryna, 1992, Polskie nazewnictwo miejskie, Warszawa.

Kosyl Czesław, 2003, Chrematonimia, [w:] Ewa Rzetelska-Feleszko, Aleksandra Cieślikowa (przy współudziale Jerzego Dumy) (red.), Stowiańska onomastyka. Encyklopedia, t. II, 370-375.

Rutkiewicz-Hanczewska Małgorzata, 2007, Nazewnictwo uzualne a teoria gier. Próba typologizacji gier onimicznych, „Onomastica” LII, 5-23.

Rutkowski Mariusz, 2001, Wstęna charakterystyka funkcji nazw własnych, „Onomastica” XLVI, 7-29.

Rzetelska-Feleszko Ewa, 1994, Najnowsze nazwy sklepów, [w:] Elżbieta Wrocławska (red.), Uwarunkowania i przyczyny zmian językowych. Zbiór studiów, Warszawa, 133-142.

Rzetelska-Feleszko Ewa, 1996, Nazwy osobowe w nazwach sklepów, [w:] Ewa Wolnicz-Pawłowska, Jerzy Duma (red.), Antroponimia słowiańska. Materiały z IX Ogólnopolskiej Konferencji Onomastycznej Warszawa 6-8 IX 1994, Warszawa, 283-289.

Rzetelska-Feleszko Ewa, 2006a, $W$ świecie nazw własnych, Warszawa-Kraków.

Rzetelska-Feleszko Ewa, 2006b, Procesy globalizacji a utrzymanie lokalnej tożsamości onimii słowiańskiej, „Onomastica” LI, 27-35.

Siwiec Adam, 2012, Nazwy wlasne obiektów handlowo-uslugowych w przestrzeni miasta, Lublin. Słownik języka polskiego, 1961, red. Witold Doroszewski, t. III, Warszawa.

Ewa Mtynarczyk

\section{Territorial and Cultural Identification in Cracovian Names of Firms}

\section{(Summary)}

Subjects of a closer analysis in the paper are Cracovian names of firms that were intended to emphasise relationships between firms or institutions and the place of their activities and thus to contribute to their territorial and cultural identification. Name-formative foundations of the analysed firmonyms are as follows: the town name (Kraków/Cracow), names of quarters and housing estates, names of streets, rivers and other stably spatially situated objects like monuments (Wawel), gates, turnpikes, forts, mounds, tenements etc. Considering specificity of Cracow and its role in the world's cultural heritage some toponyms - keeping individual identification - have much wider (national or even universal) range. Names of firms derived from such toponyms perform not only localization but also persuasive function that arouses positive feelings connected with well-known and admired town. They also perform commemorative function fixing old, not being used any more names of quarters or reminding places that are historically important for the town. The function of firmonyms derived from names of streets, objects that are only locally known, is to arouse feelings of familiarity and intimacy.

Slowa kluczowe: chrematonimia, nazwy firm, toponimia, funkcja lokalizacyjna.

Keywords: chrematonymy, names of firms, toponymy, localization function. 